\title{
ACAROLOGY
}

\section{Changes in the Reproductive Ability of the Mite Varroa destructor (Anderson e Trueman) in Africanized Honey Bees (Apis mellifera L.) (Hymenoptera: Apidae) Colonies in Southern Brazil}

\author{
Francisco E. Carneiro, Rogelio R. Torres, Roger Strapazzon, Sabrina A. Ramírez, José C.V. \\ Guerra Jr, Diego F. Koling and Geraldo Moretto \\ Depto.Ciências Naturais, Univ. Regional de Blumenau, 89010-971, Blumenau, SC
}

Neotropical Entomology 36(6):949-952 (2007)

\begin{abstract}
Alteração do Potencial Reprodutivo do ácaro Varroa destructor (Anderson e Trueman) em Colônias de Abelhas Africanizadas (Apis mellifera L.) (Hymenoptera: Apidae) no Sul do Brasil
\end{abstract}

\begin{abstract}
RESUMO - Embora o ácaro Varroa destructor tenha sido introduzido no Brasil há mais de 30 anos, ainda não foram registrados casos de mortalidade de colônias de abelhas. Nas abelhas africanizadas, a taxa de infestação obtida pelo ácaro varroa é baixa, não causando danos à apicultura brasileira. A baixa capacidade reprodutiva do parasita em células de crias de operárias das abelhas africanizadas é considerado um fator importante na manutenção do equilíbrio entre o parasita e o hospedeiro. No entanto, a possível introdução de um novo haplótipo do ácaro Varroa destructor no Brasil, ocorrida recentemente, pode estar aumentando a capacidade reprodutiva desse ácaro. A habilidade reprodutiva das fêmeas do ácaro foi avaliada em mais de mil de células de crias de operárias de abelhas africanizadas aos 17-18 dias de idade, em dois períodos. A porcentagem de fêmeas férteis do ácaro aumentou de $56 \%$ nos anos de 1980 a $86 \%$ em 2005-2006. A diferença na porcentagem de fêmeas que produziram deutoninfas, descendentes fêmeas que podem alcançar o estágio adulto ao emergir das operárias, foi ainda maior; em $2005-2006,72 \%$ das fêmeas que invadiram células de crias de operárias deixaram pelo menos um descendente viável, comparado com 35\% em 1986-1987.
\end{abstract}

PALAVRAS-CHAVE: Taxa reprodutiva, célula de cria de operária

\begin{abstract}
Varroa destructor has been in Brazil for more than 30 years, but no mortality of honeybee colonies due to this mite has been recorded. Africanized bee infestation rates attained by varroa have been low, without causing measurable damage to Brazilian apiculture. The low reproductive ability of this parasite in Africanized bee worker brood cells has been considered an important factor for maintaining the host-parasite equilibrium. Nevertheless, the possible substitution of the haplotype of the mite Varroa destructor that has occurred recently in Brazil could affected the reproductive ability of the population of this parasite in Brazil. The reproductive ability of worker of the mite females was evaluated in over one thousand 17-18day-old Africanized worker brood cells each of the two periods. The percentage of fertile mites increased from $56 \%$ in the 1980 s to $86 \%$ in $2005-2006$. The difference in the percentage of females that produced deutonymphs, female progeny that can reach the adult stage at bee emergence, was even greater. In 2005-2006, $72 \%$ of the females that invaded worker brood had left at the least one viable descendant, compared to $35 \%$ in 1986-1987.
\end{abstract}

KEY WORDS: Reproductive rate, worker brood cell

Varroa destructor (Anderson \& Trueman) is an ectoparasite mite that causes serious damages in the worldwide beekeeping. Severe mortality of honey bee colonies is common in some parts of the world and is more frequent when Apis mellifera colonies are not treated against the varroosis plague. The effects caused by $V$. destructor infestation are unequal in different parts of the world. In most parts of South America, as Brazil and Paraguay, low levels of infestation caused by $V$. destructor were registered, without causing serious problems to the bee colonies (De Jong et al. 1984, Moretto 2002). However, this mite causes more problems in temperate climates than in tropical regions (Moretto et al. 1991, De Jong \& Soares 1997). Nevertheless, it is also clear that the type of bee also affects the development of this parasite. African bees and their hybrids are more tolerant to the mite than European bee races (De Jong 1984, Moretto et al. 1991, Medina \& Martin 1999). 
The degree of tolerance to $V$. destructor among $A$. mellifera bee races appears to be related to the reproductive success of female varroa on worker brood cells. The number of descendants per female adult mite parasitizing worker brood cells is higher in European bees than in African bees and their hybrids (Camazine 1986, Moretto et al. 1991). In South and Central America, adult female mites showed reduced fecundity on Africanized A. mellifera compared to that observed with mites on European A. mellifera in Europe (Rosenkanz \& Engels 1994, Medina \& Martin 1999, Calderone et al. 2003). The reproductive ability of V.destructor female into worker brood cells appears also descendants during the pollen production than in other seasons of the year (Moretto et al. 1997).

Recently, the reproductive ability of $V$. destructor in Brazil seems to be changing. Analysis of 152 varroa females that invaded worker brood cells on Africanized bees colonies from Ribeirão Preto, São Paulo state, demonstrated that fertility levels were comparable to varroa females reproducing in worker brood cells on European bees in Germany (Garrido et al. 2003). We examined $V$. destructor reproductive ability on Africanized honey bees and compared with data that we colleted in the same region of Brazil 20 years before.

\section{Material and Methods}

Data were collected in Rio do Sul and Blumenau, Santa Catarina state, Brazil, from 1986 to1987 and from 2005 to 2006, respectively. The reproductive ability of the mite females was evaluated in 17-18 day-old Africanized worker brood cells. Monthly, from April 1986 to April 1987 (Rio do Sul) and from April 2005 to April 2006 (Blumenau), the number of Varroa eggs, protonymphs and deutonymphs was recorded from singly-infested worker-brood cells. During (40 to 120 monthly) and 1300 (100 monthly) female mites,

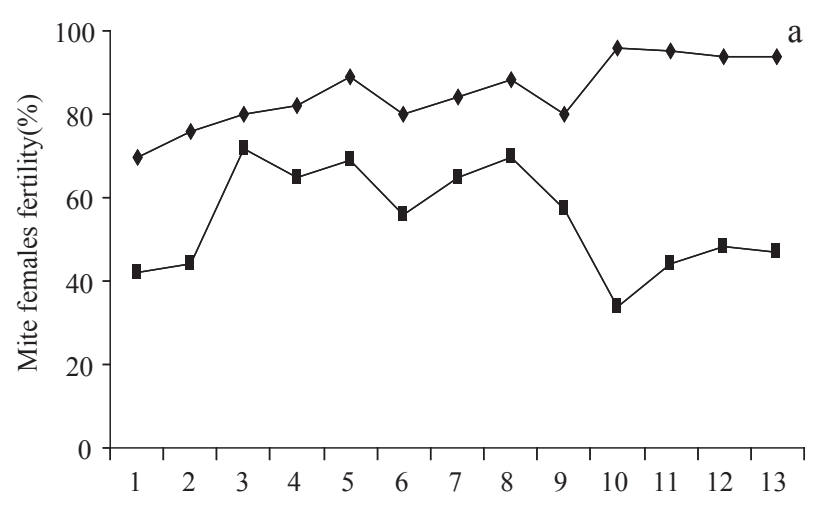
to be dependent on the season: mite females produce more the two periods the reproductive ability was studied in 1037

respectively. Statistical difference between the periods was determined by Student $t$ test.

\section{Results}

Reproductive ability of the mite $V$. destructor significantly increased from the 1980's to 2005-2006. The percentage of fertile mites (Fig. 1a) increased over 50\%, from $56 \% \pm 13 \%$ in the $1980 \mathrm{~s}$ to $86 \% \pm 8 \%$ in $2005-2006(\mathrm{t}=7.33 ; \mathrm{P}<0.00001)$. Considering the percentage of females that produced deutonymphs, female progeny that can reach the adult stage at bee emergence, the difference was even greater (Fig. 1b). In 1986-1987, only $35 \% \pm 12 \%$ of the females that invaded worker brood produced at least one descendant, compared to $72 \% \pm 8 \%$ in $2005-2006(\mathrm{t}=9.35 \mathrm{P}<0.00001)$.

Fig. 2a,b shows the mean numbers of total descendants (egg, protoymphs and deutonymphs) and only deutonymphs by adult female, respectively. Twenty years ago, each varroa female produced on average $1.7 \pm 0.47$ descendants while in 2005-2006 years was produced a mean of $2.6 \pm$ 0.58 descendants $(\mathrm{t}=5.77 ; \mathrm{P}<0.00001)$. There was also a significant increase in the number of female deutonymphs produced per female mite. In the 1980s, the mites produced a mean of $0.7 \pm 0.30$ female deutonymphs, compared to 1.4 \pm 0.75 in the more recent period $(\mathrm{t}=4.45 ; \mathrm{P}<0,00001)$. When the number of deutonymphs was compared only among fertile females, there was also a significant increase. In 1986-1987, 580 fertile females produced a mean number $1.3 \pm 0.24$ deutonymphs, while a mean number of $1.7 \pm 0.25$ was produced by 1.183 fertile females in $2005-2006(\mathrm{t}=$ $3.62 \mathrm{P}=0.001)$.

\section{Discussion}

The low reproductive ability of female $V$. destructor in worker brood cells is considered to be one of the factors

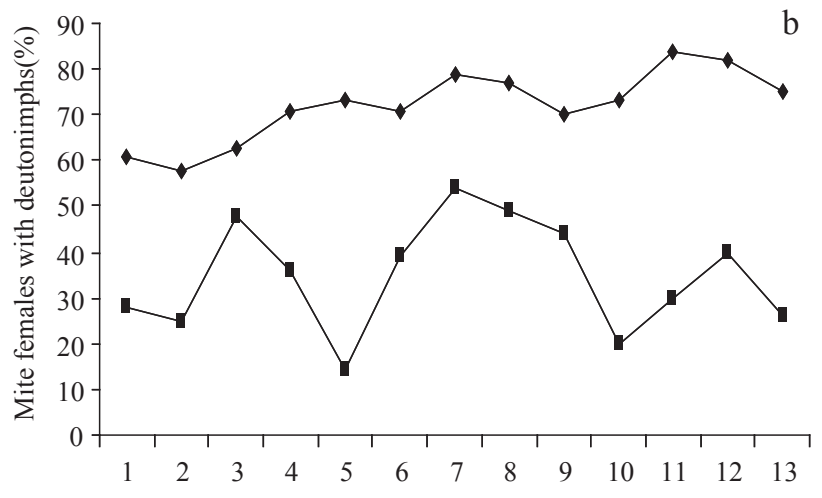

Months

$$
\longrightarrow \text { 1986-1987 period —2005-2006 period }
$$

Fig. 1. Percentage of $V$. destructor females that produced any descendants (a) and those that produced deutonimphs (effective reproduction) evaluated in 17-18 day old worker brood (b), during 1986-1987 and 2005-2006, in Africanized bee colonies in southern Brazil. 

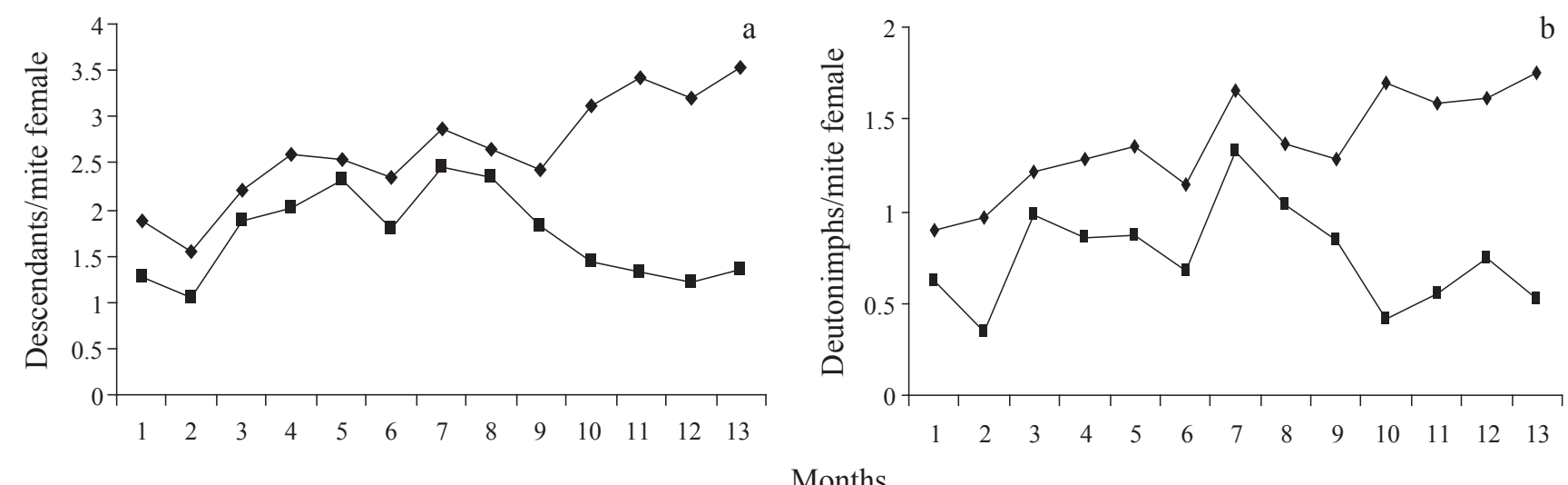

Months

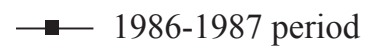

$\longrightarrow$ 2005-2006 period

Fig. 2. Number of any descendants produced by $V$. destructor females (a) and deutonimphs (effective reproduction) evaluated in 17-18 day old worker brood (b), during 1986-1987 and 2005-2006, in Africanized bee colonies in southern Brazil.

responsible for the low rates of infestation in Africanized bee colonies in South and Central America. In Brazil, even though this parasite was introduced into the country more than 30 years ago, there have been no confirmed records of colony mortality due to Varroa.

Since the 1980s, several studies have been carried out on the population dynamics of the $V$. destructor mite worldwide. Analyses of reproductive potential have consistently demonstrated that female mites produce fewer descendants in colonies of Africanized compared to European honey bees (Camazine 1986, Medina \& Martin 1999). Nevertheless, more recent data have shown changes in the reproductive potential of these mites. Results of fertility rates of female mites obtained in Rio do Sul, Santa Catarina state in the 1980s are similar to those found in other regions of the country during the same period. Approximately $50 \%$ of female mites that invaded worker brood cells of Africanized produced descendants (Rosenkranz \& Engels 1994, Camazine 1986, Moretto 2001). However, during the 1990s, it appears that there was a change in the fertility of these mites in Brazil. Starting in 1998, Correa-Marques et al. (2003); Garrido et al. (2003) observed that fertility rates raised up $80 \%$ in Ribeirão Preto São Paulo state. These results are comparable to those found in this study of 1,300 female varroa collected from worker brood cells in Africanized bee colonies in Blumenau, SC.

Along with the increase in the fertility rate (considering the proportion of females that produced any type of descendant), the mean number of progeny per female also increased significantly. Previous works reported that adult female mites in Africanized bee colonies produced approximately half as many descendants as did mites in European colonies (Camazine 1986, Moretto et al. 1996). In this study we analyzed the mean number of descendants produced per female varroa in two nearby regions in Santa Catarina state, Rio do Sul and Blumenau, which are about $80 \mathrm{~km}$ apart in 1986-1987 and 2005-2006, respectively. During the earlier period (Rio do Sul), there was a mean of 1.7 descendants per female mite. Similar mean number of descendants was also determined during this time period in apiaries of Africanized bees in Ribeirão Preto, SP and São Joaquim, SC (Moretto et al. 1996). In Blumenau, 20 years later, the female mites produced a mean of one more descendant, an increase of nearly $60 \%$. Among varroa progeny obtained in worker brood cells at 17-18 days old, only deutonymphs females can reach the adult phase until the worker bees emerges. Currently the mean number of deutonymphs produced by varroa female was also higher than those reported in 1980s and 1990s (Camazine 1986, Moretto et al. 1996).

Since the first studies on the population dynamics of the mite $V$. destructor, the race of $A$. mellifera was considered to be the main factor that influences reproductive success (Ritter \& De Jong 1984, Engels et al. 1986, Moretto et al. 1991). It is unknown whether the severity of the effects caused by the Varroa parasite depends on the genotype of the bees, on the genotype of the mite or on the interaction of both. Evidence suggests that the mite $V$. destructor is a complex species (Anderson \& Trueman 2000). A correlation between the various genotypes of the mite and its fertility in different geographical regions, might be helpful to understand the diverse effects and relationships of the mite with bees in different regions of the world. Garrido et al. (2003) found a significant increase in the fertility of female varroa under the climatic conditions of Ribeirão Preto, in the state of São Paulo, which was attributed to a change to the K haplotype (mitochondrial genomics) of varroa - type that is found in regions of the world where varroa causes great damage to apiculture. However, despite the increased reproductive potential, no increase in mite infestation rates in the colonies has been detected so far. Currently, the rate of infestation of adult bees in Africanized bee colonies in Blumenau has remained low, approximately 3\% (unpublished data). Important characteristics limiting mite populations, include removing of brood infested with varroa (hygienic behavior) (Guerra Jr. et al. 2000), mite mortality on adult bees (CorreaMarques et al. 2002, Moretto 2002) and mortality of mite offspring (Mondragón et al. 2006). These factors, determine the tolerance of these bees to the mite $V$. destructor. 


\section{Acknowledgments}

The authors thanks Dr. Sidney Luiz Stürmer for his comments and English revision and anonymous referees for corrections and suggestions.

\section{References}

Anderson, D.L. \& J.W.H. Trueman (2000). Varroa jacobsoni (Acari:Varroidae) is more than one species. Exp. Appl. Acarol. 24: 165-189.

Calderón, R.A., M.J. Sommeijer, A. De Rujter \& J.W. Veen (2003). The reproductive ability of Varroa destructor in worker brood of Africanized and hybrid honey bees in Costa Rica, J. Apic. Res. 42: 65-67.

Camazine, S. (1986). Differential reproduction of the mite Varroa jacobsoni (Mesostigmata: Varroidae) on Africanized and European honey bees (Hymenoptera: Apidae), Ann. Entomol. Soc. Am. 79: 801-803.

Correa-Marques, M.H., D. De Jong, P. Rosenkranz \& L.S. Gonçalves (2002). Varroa-tolerant Italian bees introduced from Brazil were not more efficient in defending themselves against the mite Varroa destructor than Carniolan bees in Germany, Gen. Mol. Res. 1: 153-158.

Correa-Marques, M.H., L.M. Medina, S.J. Martin \& D. De Jong (2003). Comparing data on the reproduction of Varroa destructor. Gen. Mol. Res. 2: 1- 6.

De Jong, D., L.S. Gonçalves \& R.A. Morse (1984). Dependence on climate of the virulence of Varroa jacobsoni. Bee World 65: $117-121$.

Engels, W., L.S. Gonçalves, J. Steiner, A.H. Buriolla \& M.R. Cavicchio-Issa (1986). Varroa-Befall von Carnica-Volkern im Tropenklima. Apidologie 17: 203-216.

Garrido C., P. Rosenkranz, R.J. Paxton \& L.S. Gonçalves (2003). Temporal changes in Varroa destructor fertility and haplotype in Brazil. Apidologie 53: 535-541.

Guerra Jr., J.C.V., L.S. Gonçalves \& D. De Jong (2000). Africanized honey bees (Apis mellifera L.) are more efficient at removing worker brood artificially infested with the parasitic mite Varroa jacobsoni Oudemans than are Italian bees or Italian/Africanized hybrids. Gen. Mol. Biol. 23: 89-92.

Medina, L.M. \& S.J. Martin (1999). A comparative study of Varroa jacobsoni reproduction on workers cells of honey bees (Apis mellifera) in England and Africanized bees in Yucatan, Mexico, Exp. Applied Acarol. 23: 659-667.

Mondragón, L., S. Martin \& R. Vandame (2006). Mortality of mite offspring: a major component of Varroa destructor resistance in a population of Africanized bees. Apidologie 37: 67-74.

Moretto, G. (2001). Reproduction of the mite Varroa jacobsoni Oud. in Africanized and Italian bees (Apis mellifera) during different seasonal periods. Apiacta 36: 75-80.

Moretto, G. (2002). Mortality of Varroa destructor in broodless Africanized and Carnica honey bee (Apis mellifera L.) colonies, Interciencia 27:702-704.

Moretto, G., L.S. Gonçalves \& D. De Jong (1996). The effect of climate and honeybee racial type on the reproductive ability of the mite Varroa Jacobson. Apiacta 31: 17-21.

Moretto, G., L.S. Gonçalves \& D. De Jong (1997). Relationship between food availability and the reproductive ability of the mite Varroa jacobsoni in Africanized bee colonies. Am. Bee J. 137: 67-69.

Moretto, G., L.S. Gonçalves, D. De Jong \& M.Z. Bichuette (1991). The effects of climate and bee race on Varroa jacobsoni Oud. infestation in Brazil, Apidologie 22: 197-203.

Ritter, W. \& D. De Jong (1984). Reproduction of Varroa jacobsoni O. in Europe, in the Middle East and in Tropical South America, Z. Ang. Entomol. 98: 55-57.

Rosenkranz, P. \& W. Engels (1994). Infertility of Varroa jacobsoni females after invasion into Apis mellifera worker brood as a tolerance factor against varroatosis, Apidologie 25: 402-411.

Received 27/XII/06. Accepted 05/V/07. 